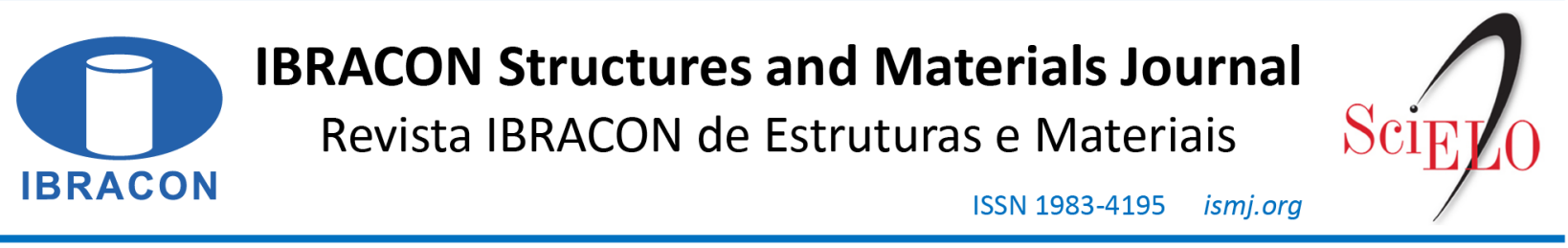

ORIGINAL ARTICLE

\title{
Study of the influence of jigging of recycled coarse aggregate on the compressive strength of concrete
}

\section{Estudo da influência da jigagem do agregado graúdo reciclado na resistência à compressão do concreto}

\author{
Gabriela Nunes Malysz ${ }^{\mathrm{a}}$ (D) \\ Denise Carpena Coitinho Dal Molin ${ }^{\mathrm{a}}$ (D) \\ Angela Borges Masuero ${ }^{a}$
}

${ }^{a}$ Universidade Federal do Rio Grande do Sul - UFRGS, Programa de Pós-Graduação em Engenharia Civil: Construção e Infraestrutura, Porto Alegre, RS, Brasil

Received 14 May 2019

Accepted 26 January 2020

\begin{abstract}
The composition heterogeneity of this type of aggregate is indicated as one of the main restrictions to its potential utilization since it generates great variability in the performance of the types of concrete produced with recycled aggregate. To reduce the use limitations of recycled coarse aggregate (RCA), this study aimed to analyze the use of a jig, a type of equipment used in mining, which performs density separation through air sprinkling in the selection of large aggregates of CDW crushing. To evaluate the equipment performance in the selection of RCA materials, specimens of concrete with recycled aggregate of three different sources were molded before and after selection in the jig, as well as reference concrete with natural aggregate. To measure the performance of the types of concrete produced, axial compressive strength tests were performed. Additionally, a statistical and comparative analysis of the results was performed to seek a better basis for possible conclusions. Analysis of the results of the axial compression strength tests showed that the variability of the recycled aggregates reflected in the inconstancy of the behavior of the concrete produced with them; it was not possible to perceive a common or uniform performance between the three sources of recycled aggregate for the mix design produced. Although some studies point to good separation results with jigging, it was found that with the use of recycled aggregates available in the local market, for the three studied sources, the selection was not able to minimize the variability of the properties of the recycled types of concrete produced with the selected aggregates.
\end{abstract}

Keywords: construction and demolition waste (CDW), recycled coarse aggregate (RCA), jig, compressive strength, variability. 
não conseguiu minimizar a variabilidade da propriedade mecânica estudada nos concretos reciclados produzidos com os agregados selecionados.

Palavras-chave: resíduo de construção e demolição (RCD), agregado graúdo reciclado (AGR), jigue, resistência à compressão, variabilidade.

How to cite: G. N. Malysz, D. C. C. Dal Molin, and A. B. Masuero, "Study of the influence of jigging of recycled coarse aggregate on the compressive strength of concrete", Rev. IBRACON Estrut. Mater., vol. 13, no. 5, e13503, 2020, https://doi.org/10.1590/S198341952020000500003

\section{INTRODUCTION}

The high consumption of construction materials, coupled with the search for sustainable development, has driven studies on the use of Construction and Demolition Waste (CDW). Recycling within the production chain itself presents itself as an alternative for the preservation of natural resources that comprise the raw material of the construction industry. Moreover, the incorporation of recycled materials as aggregates in the composition of concrete in civil construction can bring important advantages from the standpoint of sustainability, such as the reduction of landfill areas for the disposal of these materials, reduction of extraction, and use of natural aggregates from non-renewable sources. In addition to meeting a growing demand for material consumption, recycling construction and demolition waste could also minimize problems with municipal or local solid waste management [1]-[4].

According to Angulo [5], construction and demolition waste (CDW) is responsible for approximately $50 \%$ of the mass of municipal solid waste (MSW), which can be considered a significant amount of material available, with an increasing source, which makes feasible the study of its reuse. In contrast with the large generation of waste, there is a concern regarding finding good natural aggregates close to urban areas, particularly when considering transportation costs between sources and construction sites, which are becoming increasingly significant in the composition of work budgets.

Construction and demolition waste have been used for some time in paving, serving as a base and sub-base, as well as in types of concrete and blocks with or without structural function. Nevertheless, as it consists of different materials, aggregates obtained from CDW processing become extremely variable, which directly interferes with the behavior of the concrete produced with them. This circumstance can hinder, prevent, or limit its reuse or recycling [6]-[9].

Research with the use of recycled aggregates has been developed for a few years, and the variability of the materials that compose them and their properties have proved to be obstacles to their use on a large scale. Consequently, studies and proposals for methods or processes that promote the separation or selection of recycled aggregates are becoming evident [10]-[12].

In this context, this study aims to analyze the use of pneumatic jigs to promote a quick separation of the nobler materials, which can be used to replace the natural coarse aggregate in structural concrete. Thus, through laboratory experiments, it aims to research the influence of this selection on the compressive strength of the resulting types of concrete.

This study involved the analysis of the mechanical property of compressive strength in the hardened state of concrete, as it is one of the most widely evaluated concrete properties, which can be considered a parameter capable of indicating quality variations between different types of concrete.

Therefore, the study sought to contribute to the evolution of research with recycled aggregates and collaborate with the possibilities of more noble and economically more advantageous uses for these materials.

\section{MATERIALS}

The following is a description of the materials used in this research, defining the outline of this study.

\subsection{Cement}

For this research, Portland cement CP IV 32 RS, comparable to Type IP by C595/C595M [13]. which has pozzolanic additions, was used, as it is a material produced in the region where the tests are carried out and thanks to its widespread use.

The cement used has physical, chemical and mechanical characteristics according to NBR 5736 [14] and NBR 5737 [15], having a unit mass of $0.876 \mathrm{~g} / \mathrm{cm}^{3}$, a specific mass of $2.65 \mathrm{~g} / \mathrm{cm}^{3}$ and other characteristics according to tests performed, and provided by the manufacturer [16], which are presented in Table 1. 
Table 1. Chemical, physical, and mechanical properties of the cement used

\begin{tabular}{cccc}
\hline Property & CP IV 32 & Unit & Requirements \\
\hline Fineness (waste in 75 $\mu$ sieve) & 0.32 & $\%$ & $\leq 8.0$ \\
\hline Blaine fineness & 4920 & $\mathrm{~cm}^{2} / \mathrm{g}$ & $\geq 3000$ \\
\hline Start of setting & 405 & $\mathrm{~min}$ & $\geq 60$ \\
\hline Setting end time & 520 & $\mathrm{~min}$ & $\leq 720$ \\
\hline Compressive strength at 3 days & 22.3 & $\mathrm{MPa}$ & $\geq 10$ \\
\hline Compressive strength at 7 days & 26.2 & $\mathrm{MPa}$ & $\geq 20$ \\
\hline Compressive strength at 28 days & 41.2 & $\mathrm{MPa}$ & $\geq 32$ \\
\hline Fire loss (\% in mass) & 3.78 & $\%$ & $\leq 4.5$ \\
\hline $\mathrm{SO}$ (\% in loss) & 2.16 & $\%$ & $\leq 4.0$ \\
\hline $\mathrm{MgO}$ (\% in loss) & 4.21 & $\%$ & $\leq 6.5$ \\
\hline
\end{tabular}

Source: data supplied by the manufacturer (Intercement) [16]

\subsection{Natural fine aggregate}

The fine aggregate used was quartz sand, of natural origin, obtained and available in the region of the development of the study, with particle size determined by passing the material through a $\# 4.75 \mathrm{~mm}$ mesh sieve.

The sand was characterized according to its physical properties, based on the tests to determine the granulometric composition and fineness modulus according to NBR NM 248 [17], unit mass according to NBR NM 45 [18] and specific mass according to the procedure described in NBR NM 52 [19]. Before conducting the characterization tests, the samples were subjected to the quartering process as prescribed by NBR NM 27 [20], aiming to ensure that the samples represent the material as closely as possible.

The characterization tests were performed at the Construction Environment Materials and Technology Laboratory (LAMTAC/NORIE) at the Federal University of Rio Grande do Sul (UFRGS). Figure 1 shows the granulometric curve of the natural fine quartz aggregate obtained through the results of the granulometry test. As can be seen, the granulometric curve, which characterizes the fine aggregate used, is within the zone considered usable.

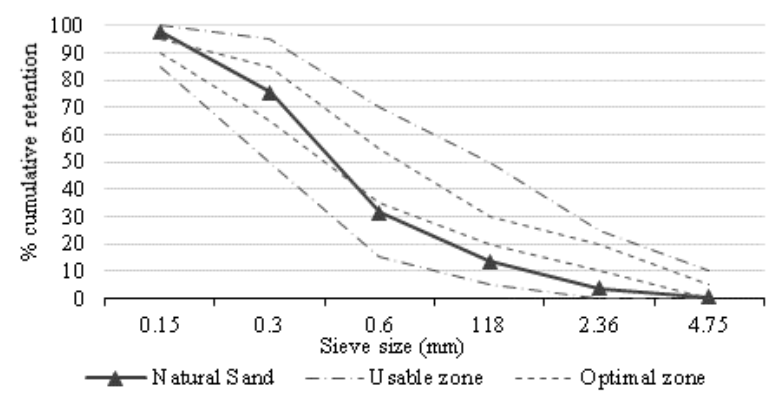

Figure 1. Granulometric curve of the natural fine quartz aggregate.

The results for the fineness modulus, maximum aggregate size, specific gravity, and unit mass are shown in Table 2 . The characteristics found meet the requirements established by the NBR 7211 standard [21].

Table 2. Physical properties of the fine aggregate

\begin{tabular}{cccc}
\hline Property & Values & Unit & Standard \\
\hline Fineness Module & 2.22 & - & NBR NM 248 [17] \\
\hline Maximum Dimension & 2.40 & $\mathrm{~mm}$ & NBR NM 248 [17] \\
\hline Specific Mass & 2.507 & $\mathrm{~g} / \mathrm{cm}^{3}$ & NBR NM 52 [19] \\
\hline Unit mass & 1.54 & $\mathrm{~g} / \mathrm{cm}^{3}$ & NBR NM 45 [18] \\
\hline
\end{tabular}

\subsection{Natural coarse aggregate}

The natural coarse aggregate used was of basaltic origin, with dimensions between $25 \mathrm{~mm}$ and $4.8 \mathrm{~mm}$, obtained in the city of Montenegro, in the Brazilian state of Rio Grande do Sul (RS), and sold in the region where the study was developed. 
Prior to conducting the characterization tests, the samples were subjected to the quartering process as prescribed by NBR NM 27 [20], aiming to ensure that the samples represent as closely as possible the material. All characterization tests were performed at the Construction Environment Materials and Technology Laboratory (LAMTAC/NORIE) at UFRGS.

The coarse natural aggregate was characterized as to its physical properties according to the determination tests of the granulometric composition of NBR NM 248 [17]. The granulometric curve characteristic of the natural coarse aggregate can be seen in Figure 2, alongside the delineation of the granulometric zone 9.5/25, as specified by the standard to which the results most fit, although it presented a point outside the boundary.

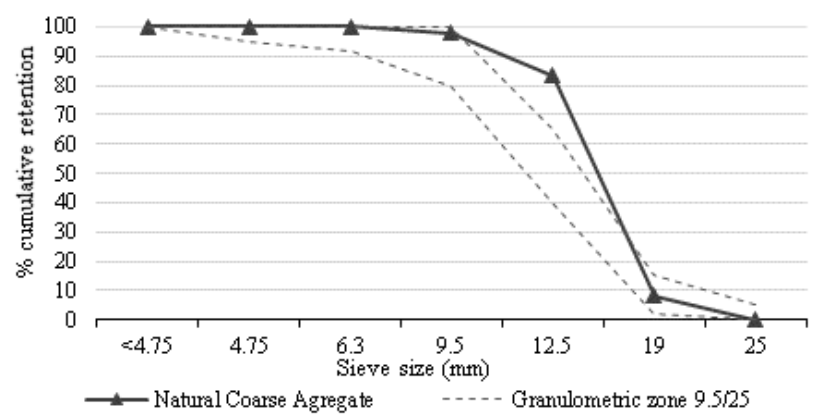

Figure 2. Granulometric curve of the natural coarse basaltic aggregate.

Unit mass tests were carried out according to NBR NM 45 [18], index as prescribed in NBR 7809 [22], specific mass and absorption described in NBR NM 53 [23], the results of which are presented in Table 3 and through which it is possible to observe the fulfillment of the requirements established in the NBR 7211 standard [21].

Table 3. Physical properties of the fine aggregate

\begin{tabular}{cccc}
\hline Property & Values & Unit & Standard \\
\hline Fineness Module & 7.06 & - & NBR NM 248 [17] \\
\hline Shape Index & 2.20 & - & NBR 7809 [22] \\
\hline Water Absorption & 0.023 & $\%$ & NBR NM 53 [23] \\
\hline Maximum Dimension & 25 & $\mathrm{~mm}$ NM 248 [17] \\
\hline Specific Mass & 2.964 & $\mathrm{~g} / \mathrm{cm}^{3}$ & NBR NM 53 [23] \\
\hline Unit Mass & 1.694 & $\mathrm{~g} / \mathrm{cm}^{3}$ & NBR NM 45 [18]
\end{tabular}

\subsection{Recycled coarse aggregate}

\subsubsection{Constitution}

Construction and demolition waste generally have a high degree of heterogeneity in their composition. For this reason, constitution or composition tests were carried out, with the aim of characterizing the samples of recycled coarse aggregate as to the parcels coming from the different materials that compose them.

The constitution or composition test was performed manually by visually separating the constituent materials from three representative samples of each batch of recycled coarse aggregate, before and after the jigging process. The samples were previously oven-dried until achieving mass consistency, and aggregates with particle size between 25 and 4.75 millimeters were analyzed, with the passing of material in this last sieve being disregarded.

The samples were weighed, and each piece of material was then separated and weighed separately. The mass percentages of each constituent material in relation to the total mass of the sample were obtained. The final result was achieved through the mean value of the percentages obtained in the analyses carried out by three different persons, seeking a result that could be deemed more assertive and closer to the reality of the materials that compose the batch of recycled coarse aggregate.

The following is the classification of the CDW following separation. In this research, the most representative materials, which were used for separation and classification, were: 
a) Mortar: considering all cementitious material consisting of sand and cement and/or lime, which visually did not contain coarse aggregates or gravel;

b) Concrete: any material composed by the union of sand, cement and coarse aggregate, whose identification was possible;

c) Rock: any fragment of natural rock, which may have the presence of some adhered agglomerating material in a small amount, constituting in its largest portion of rocks of different types, except sandstone;

d) Rock - sandstone: fragments of natural rock that have been identified as sandstone;

e) Ceramics: all unpolished ceramic material, consisting essentially of bricks and ceramic tiles;

f) Ceramics - enameled or polished: a portion composed of ceramic materials with at least one of its surfaces being polished and enameled, such as tiles, enameled ceramic tiling, sinks, and sanitary ware;

g) Mixed: aggregates that were visually formed by two materials, with no predominance of either.

h) Tailings: other materials that have not been previously classified, considered as contaminants, such as wood, metals, plastics, asbestos, clods of earth or lime, organic materials, glass, plaster, and coal, among others.

Table 4 shows the fractions, in percentage values, of each classified material, for the three sources studied and for the jigged and non-jigged plots. As shown in Table 4, the three sources studied have highly different compositions. Source 1 has significant amounts of sandstone and presents the highest fraction of concrete aggregates. The analysis of source 2 indicates the presence of a larger portion of mortar and ceramic material, including enamel. In turn, source 3 , despite being processed and collected at the same location as source 2, but from different batches of CDW, does not present similar characteristics, having the highest amounts of rocks and mixed material among the studied sources.

Table 4. Composition of the different materials obtained from the studied sources, before and after jigging, in percentage (\%)

\begin{tabular}{|c|c|c|c|c|c|c|}
\hline MATERIAL & RCA1 & RCA1J & RCA2 & RCA2J & RCA3 & RCA3J \\
\hline Mortar & 28.3 & 27.2 & 37.5 & 33.7 & 29.1 & 35.3 \\
\hline Concrete & 11.8 & 11.8 & 4.2 & 4.8 & 6.5 & 6.0 \\
\hline Rock & 32.8 & 36.6 & 18.4 & 21.3 & 38.7 & 32.0 \\
\hline Sandstone & 22.6 & 20.9 & 0.8 & 0.8 & 14.7 & 9.8 \\
\hline Others & 10.2 & 15.7 & 17.6 & 20.5 & 24.0 & 22.2 \\
\hline Ceramics & 25.6 & 22.0 & 37.3 & 37.7 & 21.5 & 21.2 \\
\hline non-enameled & 21.9 & 17.2 & 25.6 & 22.2 & 10.7 & 13.9 \\
\hline Enameled & 3.7 & 4.8 & 11.7 & 15.5 & 10.8 & 7.3 \\
\hline Mixed & 0.3 & 1.3 & 1.8 & 1.8 & 4.0 & 5.2 \\
\hline Tailings & 1.2 & 1.1 & 0.8 & 0.7 & 0.2 & 0.4 \\
\hline
\end{tabular}

Legend: RCA1 = Recycled Coarse Aggregate from Source 1, RCA1J= Recycled Coarse Aggregate from Source 1 selected by jigging, RCA2 $=$ Recycled Coarse Aggregate from Source 2, RCA2J= Recycled Coarse Aggregate from Source 2 selected by jigging, RCA3= Recycled Coarse Aggregate from Source 3, RCA3J $=$ Recycled Coarse Aggregate from Source 3 selected by jigging.

\subsubsection{Granulometric composition and fineness module}

The granulometric composition tests were performed according to the prescription of NBR NM 248 [17], through which the maximum characteristic dimension of $25 \mathrm{~mm}$ was obtained for sources 1 and 3 , while $19 \mathrm{~mm}$ was obtained for source 2, and a fineness module ranging from 6.66 and 7.06 for the recycled aggregates used in this research. Figure 3 shows the granulometric curves for each recycled aggregate configuration, coupled with the results obtained for the natural coarse aggregate and the limits established by the NBR 7211 standard [21].

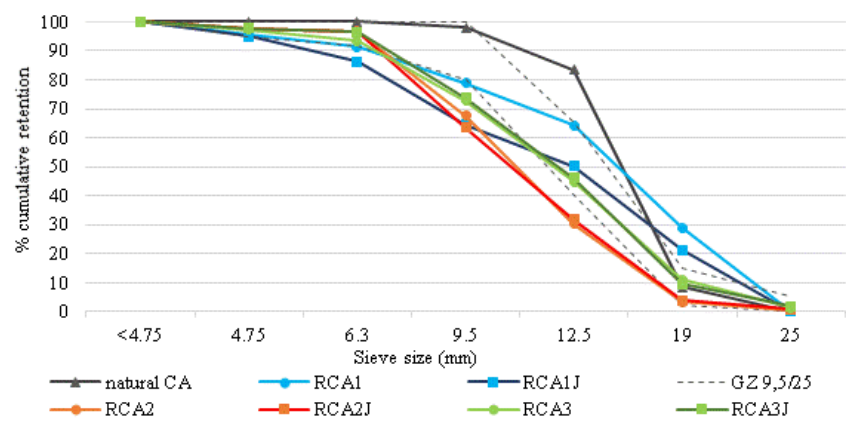

Figure 3. Granulometric curves of recycled coarse aggregates from sources 1, 2 and 3. 
It can be observed that the granulometric composition of the natural aggregate and some recycled aggregates used in the research did not fully fit the limits of the granulometric zone 9.5/25 (established by NBR 7211 [21]) and used in this study for comparative purposes. Irrespective of comprising coarse, natural, or recycled aggregates, in some cases, not being fully included in the granulometric composition ranges determined by the standard, they were used without alterations or framing in terms of particle size. This choice aimed to employ recycled aggregates in the way they are arranged in the sources and how they are produced, avoiding imposing an additional processing step to their application and use.

\subsubsection{Shape index}

To determine the shape index, the direct method based on measurements of 200 particles with the use of a caliper was adopted, as prescribed by NBR 7809 [22]. The shape index is obtained by the ratio between the maximum length and the minimum thickness of all the measured grains, weighted by the number of grains retained in each granulometric fraction.

The results for this test are shown in Figure 4, for all coarse aggregates involved in the experimental phase of this study, alongside the limit indicated by the standard as the ideal quantity for use in concrete. Considering that the aggregates with cubic grains, considered as the optimal form for crushed aggregates, have an index close to 1, the grains considered lamellar have higher values, i.e. above 2 . The higher these values are, the more lamellar is the shape of the grain. Thus, the values obtained indicate that the recycled aggregates can be considered more lamellar.

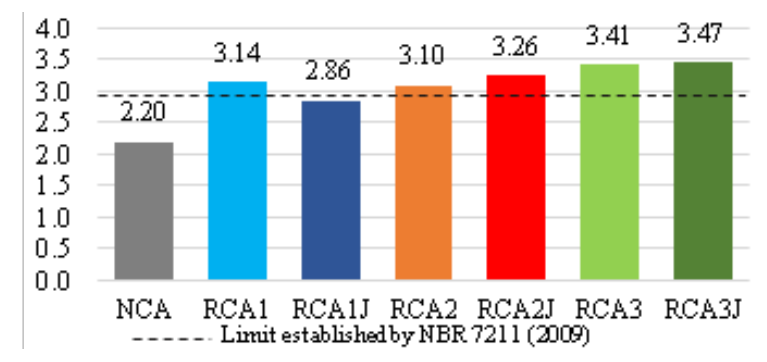

Figure 4. Shape index of the natural and recycled coarse aggregates from sources 1, 2 and 3, before and after jigging.

\subsubsection{Unit mass and specific mass}

The specific mass is the relation between the dry aggregate mass and its volume, without considering waterpermeable pores. The specific mass test adopted was the methodology developed by Leite [1], as it is believed to be the most suitable for recycled coarse aggregates.

Figure 5 shows the specific masses of recycled coarse aggregates, obtained through Leite's method [1]. Additionally, the value obtained for the natural coarse aggregate is presented, seeking a reference and comparison of the magnitude of the result.

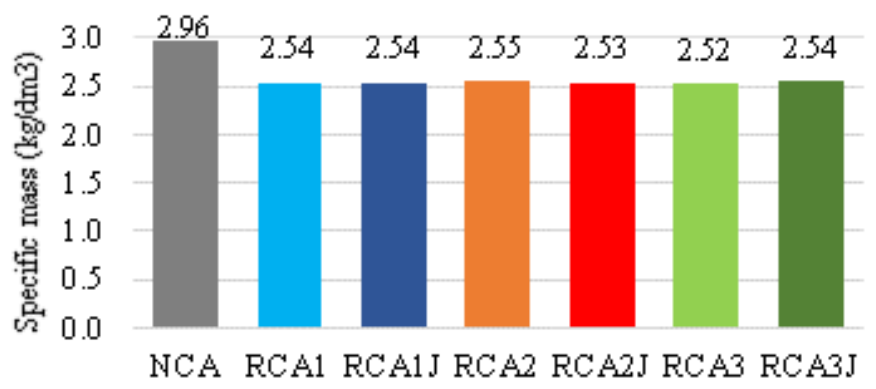

Figure 5. Specific mass of the recycled coarse aggregates from sources 1, 2 and 3.

As shown in Figure 5, the recycled aggregates had a specific mass lower than that of natural aggregates. When comparing the specific mass values between the recycled coarse aggregates analyzed, they did not present significant differences among themselves as to the processing performed for each source or among the different sources. 
The values obtained for the unit mass of the aggregates used in this study are shown in Figure 6, in which the results ranged between $1.10 \mathrm{~g} / \mathrm{cm}^{3}$ and $1.20 \mathrm{~g} / \mathrm{cm}^{3}$ for recycled aggregates. Compared to the unit mass value of the natural coarse aggregate, the results found for all recycled aggregates studied were lower; however, when comparing the values of sources 1 and 2 before and after jigging, there is a slight increase in values.

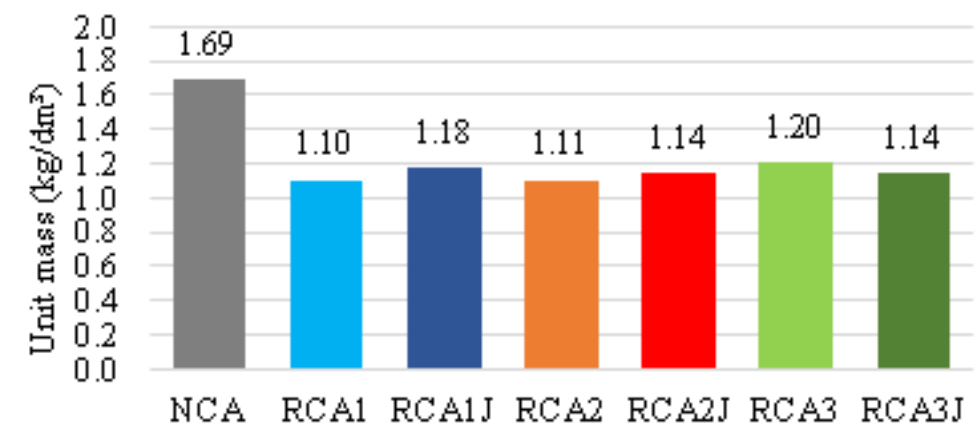

Figure 6. Unit mass of the recycled coarse aggregates from sources 1, 2 and 3

\subsubsection{Water absorption}

The determination of the absorption rate of the recycled aggregates is important for the study of the dosage of types of concrete that will use this material, as the recycled aggregate is a material with higher porosity than the natural aggregate [24]. In this study, the method chosen to assess the absorption rate was the one presented by Leite et al. [25], which was adapted from the method proposed by Leite [1]. This test methodology has better applicability and shows more realistic results for recycled coarse aggregates, thanks to the high porosity and the possibility of material loss due to disintegration.

Figure 7 illustrates the results obtained for the tests performed, in which it can be seen that the natural coarse aggregate used as a reference - of basaltic origin and with very low porosity - presents extremely low absorption rates when compared with the rates achieved by recycled aggregates. Nevertheless, when comparing the results obtained for each source of recycled coarse aggregate, before and after jigging, it can be seen that there was a reduction in the absorption rates, which can be attributed to the density selection carried out on these materials.

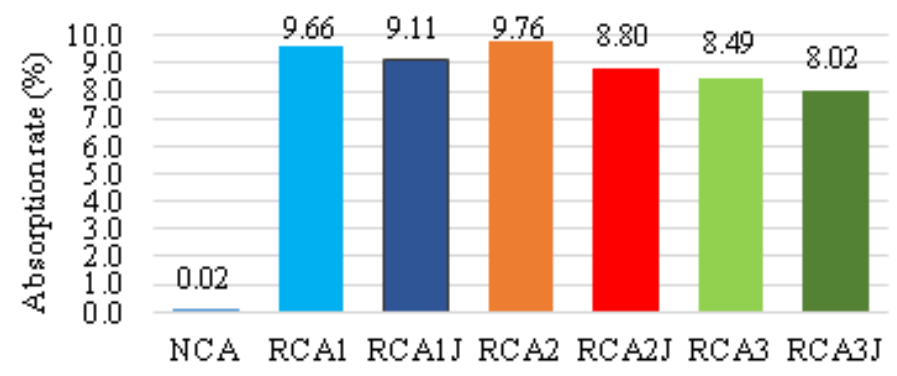

Figure 7. Absorption rate of the natural and recycled coarse aggregates

\subsection{Water}

The water used for the production of concrete, as well as for saturation of recycled aggregates and the performance of certain tests, was obtained at the public supply network of the city of Porto Alegre, in the state of Rio Grande do Sul, Brazil.

\section{EXPERIMENTAL PROGRAM}

The experimental program of this research was designed with the aim of analyzing the properties of the concrete produced with recycled coarse aggregate before and after the processing of these aggregates via jigging. To this end, three different sources of aggregates obtained by the construction and demolition waste crushing process were studied. Suppliers market or dispose of recycled aggregates with a particle size between $4.75 \mathrm{~mm}$ and $25 \mathrm{~mm}$, with all the material necessary to carry out this research obtained through donation. 
Characterization tests were carried out, with representative samples of the aggregates, before and after jigging. The characterization tests selected included those most performed in studies with coarse aggregate, which were presented in item 2. The relevance of these tests is justified by the fact that the results obtained may have an influence on their method of disposal into cementitious matrices, workability, and cement consumption, thereby reflecting the consistency and compactness of the resulting concrete and affecting the performance and costs of types of concrete made with these materials [26].

Three concrete mixes were molded for each sample of recycled aggregate (jigged and non-jigged). The three features chosen for this research were compositions with more resistant matrices, intending to verify the resistance of the recycled aggregate in the recycled concrete, as opposed to the matrix. Reference concrete was also produced with natural coarse aggregates, for comparative analysis.

\subsection{Sampling}

The acquisition of recycled aggregates was carried out in landfills, demolition companies, and non-governmental organizations, which receive or collect construction and demolition waste. These institutions perform the visual and manual removal of impurities and process this material in crushers for later sale or donation.

In this research, Source 1 comprises the coarse aggregates recycled from the company that collects CDW through dumpsters, performs the material crushing, and markets the recycled aggregates in three granulometric ranges. The company is in the city of Montenegro, RS, and the collection was carried out in May 2017. The recycled bulk CDW aggregates from Source 2 were obtained from a non-governmental organization in the south of the city of Porto Alegre in November 2017, with the NGO receiving construction and demolition waste from the community in which it is inserted, performing the crushing and donating this material to the local population. For the Source 3 of recycled coarse aggregates, the materials were obtained at the same location as Source 2. These, however, came from the processing of a different batch of construction and demolition waste, crushed, and collected in February 2018.

The collections were carried out with the aid of a shovel and the material was collected along the entire height of the pile. The recycled aggregates were packed in 30 bags for the storage and transportation of construction materials. Upon arrival at the laboratory, the bags were weighed, their masses being between the values of $30 \mathrm{~kg}$ and $36 \mathrm{~kg}$, with the total material collected close to 1 metric ton.

The recycled coarse aggregates were homogenized and quartered using the procedure described in NBR NM 27 [20], from which the necessary quantities of the material were separated, in terms of mass, for each of the tests carried out and for subsequent preparation of the types of concrete. Through this technique, samples of material from each source were separated (around 70\% of the total), which were transported to the Mineral Processing Laboratory (LAPROM) of the Federal University of Rio Grande do Sul to be processed in the pneumatic jig.

\subsection{Separation tests}

The particle separation method selected for the development of this research was air jigging, which was carried out using a pneumatic jig. This choice was made as it is a type of equipment capable of processing large amounts of material, with studies that show its good performance in the selection of particles with particle size close to those of the coarse aggregate, as well as thanks to its low cost of acquisition and maintenance, which increases the possibilities of applying the process on a large scale.

As described by Sampaio and Tavares [27], the first step in the sequence of the jigging operation concerns the selection of the equipment's operating settings. For this choice, a search was made for works that carried out the process of jigging with construction and demolition waste, such as those published by Cazacliu et al. [28], Silva et al. [29], Ambrós [30], Sampaio et al. [31], and Cunha [32], among others. In parallel, pilot tests were carried out with the recycled aggregates from Source 1. Based on the parameters already used by the aforementioned researchers, tests were carried out to adapt the processed material to the operating parameters of the jig. The visual analysis of the stratification of the layers of the material, coupled with the experience of the equipment operator and the values previously adopted in other studies pointed to the choice of the criteria that were used. These operating parameters of the equipment were introduced in the control panel and kept constant for the three evaluated sources. They are:

a) Frequency of $180 \mathrm{rpm}$, which is the rate of air pulsation in the stratification chamber;

b) Expansion Bed rate of $70 \%$, due to the power of the airflow;

c) Processing time of 120 seconds.

The amount of material used in each jigging process was approximately $60 \mathrm{~kg}$, and the expectation after jigging was that the denser coarse aggregates would be deposited in the lower tray from which they were collected. At the end of 
each test, the material was collected from the lower layer of the separation chamber. After the processing of the coarse aggregates, the total amount collected, from each specific source, was again homogenized and quartered in the portions necessary to carry out the characterization and preparation of types of concrete tests, aiming to ensure that all portions of samples were representative of the material.

\subsection{Production of the concretes}

The recycled coarse aggregates underwent the wetting or pre-saturation stage before making the mixtures for concrete, aiming to compensate for the difference in absorption between natural and recycled aggregates [33], [34].

The research sought to stipulate a standard procedure for all recycled aggregates that were studied, the immersion time being chosen based on the absorption rate obtained in the first test performed for Source 1. The aggregates were submerged for 2 hours, seeking a minimum saturation of $80 \%$. Afterwards, they were placed in a sieve, with a mesh opening of $0.15 \mathrm{~mm}$, for drying in open air, for a period of 4 hours, until the condition of saturation with a dry surface was obtained.

\subsection{Experimental dosage and definition of the reference line and recycled concrete}

The dosage method adopted for this study was the IPT/EPUSP developed by Helene and Terzian [35], which consists of adjusting the ideal mortar content by setting the Slump cone test value (as prescribed in NBR NM 67 [36]), taking it as a control parameter. Aiming at a better analysis of the concrete behavior, three mass mixes were made for each aggregate to be studied, with lower, intermediate, and higher consumption of cement, which can be called, in a simplified way, poor, intermediate and rich mixes. The workability adjustment was performed exclusively by correcting the amount of water necessary to achieve the reduction defined for this research, set at $100+/-20 \mathrm{~mm}$, i.e., plasticizers or superplasticizers were not used to obtain the predetermined consistency.

The materials were mixed using a concrete mixer with a vertical axis previously imprinted with the application of a mixture of cement, natural fine aggregate, and water, both in its drum and in its shovels. The idea of priming aims to prevent the mortar from the first concrete mixture from being lost because of the concrete mixer walls or from adhering to the paddles. Soon after, the priming mortar was removed and discarded, so that the mixtures could then be made.

The order of placing the materials in the mixer was as follows: cement, sand, and an initial amount of water, to provide a kind of bed to protect the recycled aggregates and avoid breaking the grains and altering their particle size by the movement of the concrete mixer, as recommended by Cordeiro's research [24].

Unit mixes were made in relation to the $1: \mathrm{m}$ cement mass, where $\mathrm{m}$ is the sum of the mass quantities of coarse and fine aggregates. The experimental dosage was carried out with the recycled coarse aggregates from source 1 (RCA1), with mixtures being produced for the unitary mix in relation to the cement mass quantities of 1:2.5; 1:4, and 1:5.5. Concreting started with the intermediate line with $\mathrm{m}$ equal to 4 , followed by the rich and poor lines, with values of $\mathrm{m}$ equal to 2.5 and 5.5 , respectively. The ideal mortar content, defined experimentally, was $55 \%$.

The consistency determination was performed through the Slump Clone Test, as prescribed in NBR NM 67 [36], and the amount of water used in the mixture was quantified to reach the defined values of $100+/-20 \mathrm{~mm}$.

The experimental program included the implementation of types of concrete for the unit mixes in relation to the cement mass quantities of 1:2.5; 1:4.0 and 1:5.5 with natural coarse aggregate (reference) and for the three batches of recycled coarse aggregate before and after jigging.

\subsection{Production of specimens}

For each of the twenty-one mixes defined, six cylindrical specimens were molded, with dimensions of $10 \times 20 \mathrm{~cm}$, for the performance of the axial compressive strength tests, and the manufacture of the specimens followed the parameters established by NBR 5738 [37] for molding and curing. All the test specimens (TSs) relating to a specific concrete mix were molded simultaneously. After pouring and filling the metal molds, they were compacted on a vibrating table. The preparation of the metal molds was carried out through the cleaning and application of release agent (mineral oil) to facilitate their dismantle or removal.

After molding, the specimens were covered with a plastic bag to avoid water loss, being kept in the test site during the first 24 hours. Subsequently, they were dismantled and stored in a wet chamber with a controlled temperature of 23 $+/-2^{\circ} \mathrm{C}$ and relative humidity of $90-100 \%$ to ensure curing during the period stipulated for carrying out the tests in a hardened state. 


\subsection{Axial compressive strength test}

For the evaluation of the influence of the density separation process of the recycled coarse aggregate on the behavior of the hardened concrete, axial compression resistance tests were carried out, according to procedures prescribed in NBR 5739 [38].

The standard time adopted for the analysis of the mechanical property of types of concrete was 28 days, and all specimens had their bases previously rectified as recommended in NBR NM 77 [39].

All tests of this research were carried out at the Construction Environment Materials and Technology Laboratory (LAMTAC/NORIE), located at central campus of the Federal University of Rio Grande do Sul, using the computerized press of the EMIC MCT30 PC 200i model, with repetitions performed for three specimens per family of concrete produced.

\section{RESULTS AND DISCUSSIONS}

The results achieved for the axial compressive strength of the produced concrete are shown in Table 5. Each value represents the average of three experimental observations, the standard deviation of these results, and the coefficient of variation also being described. To facilitate the visual analysis, the values were plotted in Figure 8.

Table 5. Mean, standard deviation and coefficient of variation of axial compressive strength (MPa).

\begin{tabular}{ccccc}
\hline Aggregate type & Unit mix & Mean (MPa) & Standard deviation (MPa) & CV (\%) \\
\hline NCA & 2.5 & 35.18 & 0.96 & 1.45 \\
\hline & 4.0 & 31.51 & 0.04 & 4.6 \\
\hline & 5.5 & 24.88 & 1.04 & 0.1 \\
\hline RCA1 & 2.5 & 22.16 & 0.57 & 3.7 \\
\hline & 4.0 & 18.80 & 1.03 & 7.1 \\
\hline RCA1J & 5.5 & 14.52 & 1.63 & 6.6 \\
\hline & 2.5 & 24.73 & 0.70 & 3.1 \\
\hline RCA2 & 4.0 & 22.54 & 0.75 & 4.3 \\
\hline & 5.5 & 17.30 & 2.22 & 8.4 \\
\hline RCA2J & 2.5 & 26.35 & 0.41 & 1.19 \\
\hline RCA3 & 4.0 & 20.68 & 1.44 & 8.0 \\
\hline & 5.5 & 14.86 & 0.76 & 5.8 \\
\hline RCA3J & 2.5 & 24.96 & 0.91 & 3.8 \\
\hline & 4.0 & 19.84 & 1.05 & 5.4 \\
\hline & 5.5 & 16.86 & 1.55 & 4.5 \\
\hline & 2.5 & 23.08 & 1.24 & 8.7 \\
\hline & 4.0 & 17.83 & 1.80 & 6.8 \\
\hline & 5.5 & 18.13 & 1.55 & 8.1 \\
\hline
\end{tabular}

Legend: $\mathrm{NCA}=$ Natural Coarse Aggregate, RCA1 = Recycled Coarse Aggregate from Source 1, RCA1J= Recycled Coarse Aggregate from Source 1 selected by jigging, RCA2 = Recycled Coarse Aggregate from Source 2, RCA2J = Recycled Coarse Aggregate from Source 2 selected by jigging, RCA3= Recycled Coarse Aggregate from Source 3, RCA3J= Recycled Coarse Aggregate from Source 3 selected by jigging.

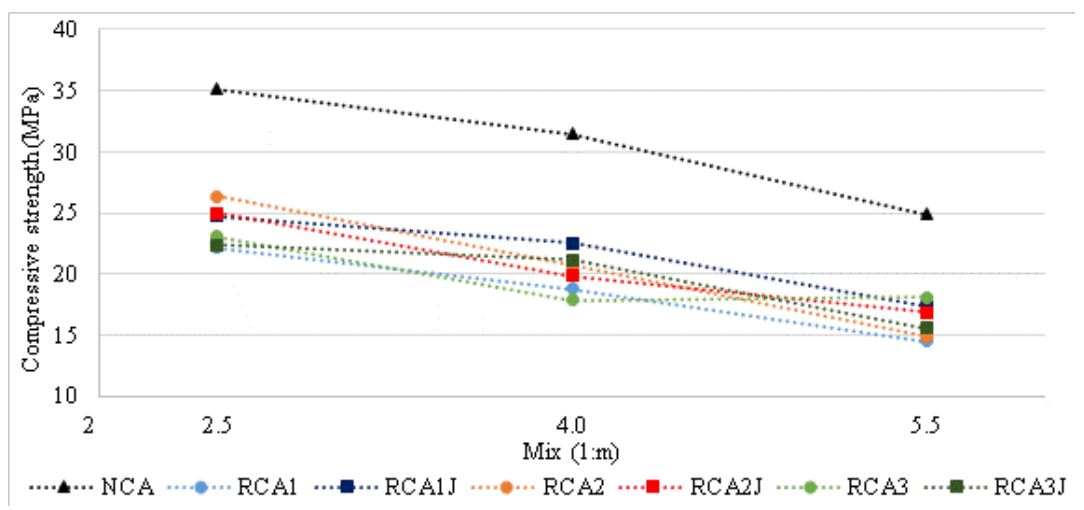

Figure 8. Influence of the mix on the axial compressive strength at 28 days (MPa) 
Due to the variability of recycled aggregates, the types of concrete produced with them also showed inconsistent behavior. As shown in Figure 8, there was no common or uniform performance among the three sources of recycled aggregate for the three mixes produced.

Still, in Figure 8, the analysis of the values for the types of concrete produced with aggregates from source 1 revealed an increase in compressive strength of the recycled aggregates compared to those that were not selected by jigging, for all mixes investigated. For source 2, the results obtained were different from those expected, and the aggregates that did not undergo density selection showed better performance for the rich and intermediate mixes, while the selected aggregates showed better results only for the poorest cement mix. For source 3 , it can be concluded that jigging did not promote improvements for the rich and poor cement mixes, presenting gains for the axial compressive strength parameter only for the intermediate mix.

Thus, Figure 8 shows that the only aggregates that showed gains in the axial compressive strength values, for all mixes that underwent the density separation process were the aggregates from source 1 . The same could not be stated for sources 2 and 3, which show a reduction in the compressive strength value for some mixes. A hypothesis for this behavior can be because source 1 has a smaller amount of enameled and polished ceramic lamellar material. Such peculiarity may have generated interferences in the density separation process, as it was possible to observe in the information on the characterization of composition, particle size, shape index and unit mass of the recycled aggregates analyzed, while for source 1, gains and improvements could be identified, as opposed to what was observed for the other sources.

Aiming at a more consistent evaluation of the axial compression resistance data, a statistical treatment was performed using the analysis of variance (ANOVA). The results obtained can be seen in Table 6 .

Table 6. Analysis of Variance (ANOVA) for compressive strength.

\begin{tabular}{cccccccc}
\hline Variation source & SQ & GDL & MQ & Test F & Probability & Significance \\
\hline A: RCA Source & 5.58 & 2 & 2.79 & 1.82 & $17.70 \%$ & NO \\
\hline B: Selection by Jigging & 9.07 & 1 & 9.07 & 5.90 & $2.02 \%$ & YES \\
\hline C: Mix & 533.99 & 2 & 266.99 & 173.82 & $0.00 \%$ & YES \\
\hline AB & 22.83 & 2 & 11.41 & 7.43 & $0.20 \%$ & YES \\
\hline AC & 28.51 & 4 & 7.13 & 4.64 & $0.40 \%$ & YES \\
\hline BC & 5.84 & 2 & 2.92 & 1.90 & $16.43 \%$ & NO \\
\hline ABC & 16.26 & 4 & 4.07 & 2.65 & $4.91 \%$ & YES \\
\hline Error & 55.30 & 36 & 1.54 & & & \\
\hline TOTAL & 677.37 & 53 & & & &
\end{tabular}

To assess this study, a significance level of $5 \%$ was considered, in which only factors or combinations with a probability of less than 5\% are considered significant, i.e., they cause changes in the response variable. Therefore, through the analysis of variance, the source effect of the recycled aggregates did not have a significant impact on the axial compressive strength results. The controllable factors evaluated represented by the letters B and C (processing and mix, respectively) were significant, concomitantly with the interactions $\mathrm{AB}$ and $\mathrm{AC}$. Thus, these factors and interactions will be shown separately below.

Figure 9 shows the isolated effects for the selection by jigging (a) and the mix (b) on the compressive strength, through the mean and standard deviation bars, of all observations referring to recycled aggregates that have not undergone treatment, as well as the recycled aggregates that were selected by jigging and through the mean axial compressive strength values obtained for each line.
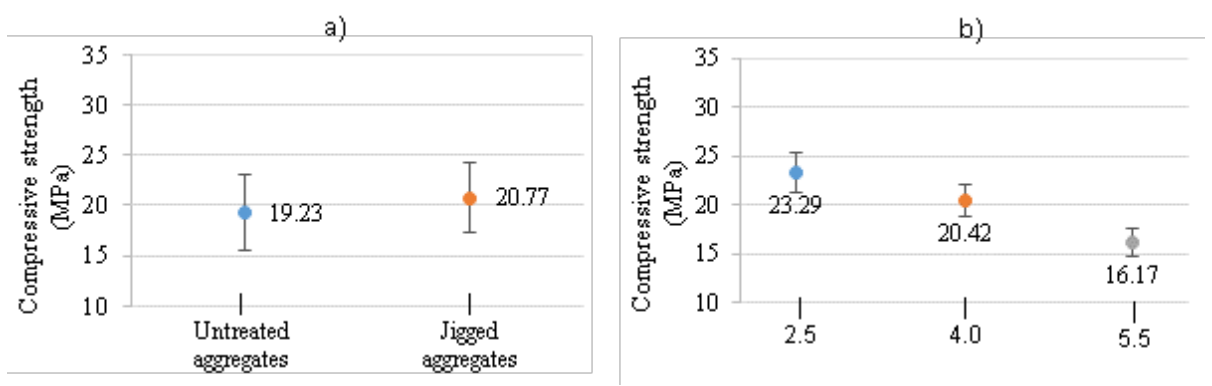

Figure 9. Isolated effects in axial compressive strength. 
As shown in Figure 9a, for all sources and all mixes produced, the mean results of the axial compression test for the aggregates that were selected by jigging show slightly higher values than those that did not undergo this process. The analysis of variance shows significant improvement and considers that the processing has an impact on the values for the analyzed parameter. In mining, the jigging process provides the selection of the densest materials, so it was expected that there would be a separation of the most resistant aggregates. This may explain the fact that the compressive strength values of types of concrete produced with the aggregates selected in the jig are higher than those that were not been processed.

The knowledge that the mix, particularly water/cement ratios used in concrete mixtures, is impactful for the strength values achieved by concrete in the hardened state is already a consensus in the scientific community. Complementing the results and justifications presented in Figure 9b, for the axial compressive strength results of types of concrete per line used, its isolated effect shows that the richer the line is (the lower water/cement ratio), the higher the values reached for the compressive strength of concrete.

Figure 10 shows the interaction of the effects of the source and the selection by the density of the recycled aggregates studied, in relation to the response variable. For sources 1 and 3, the separation process by jigging generated strength gains in the types of concrete produced with the processed aggregates, whereas for source 1, this increase was more noticeable. Nevertheless, there was an inversion in source 2, in which the density selection generated discrete losses in the strength values.

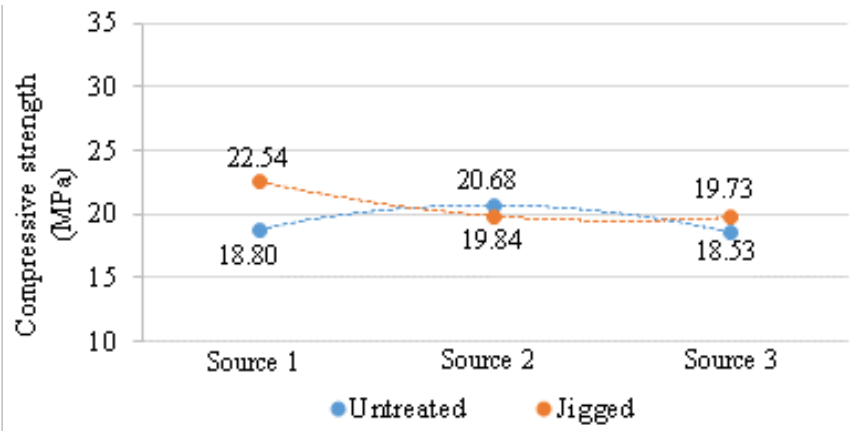

Figure 10. Effect of the source-treatment interaction in axial compressive strength.

The variability of the materials that make up the recycled aggregates, as evidenced in their characterization tests, coupled with the difficulty in promoting an effective separation of their components using jigging, may have influenced the results, which did not show significant gains as expected, particularly for sources 2 and 3 .

The effectiveness of jigging is linked to the source of origin of the recycled aggregate, through the composition of the CDW and form of crushing. Contrary to what was expected, the density selection was not able to reduce the variability of the axial compressive strength of types of concrete produced with aggregates, since by comparing the values obtained between the sources, it is not possible to notice a constant behavior or close results, among them, for this mechanical property.

Figure 11 shows the effect of the interaction between the studied traits, and the sources from which the recycled aggregates were obtained.

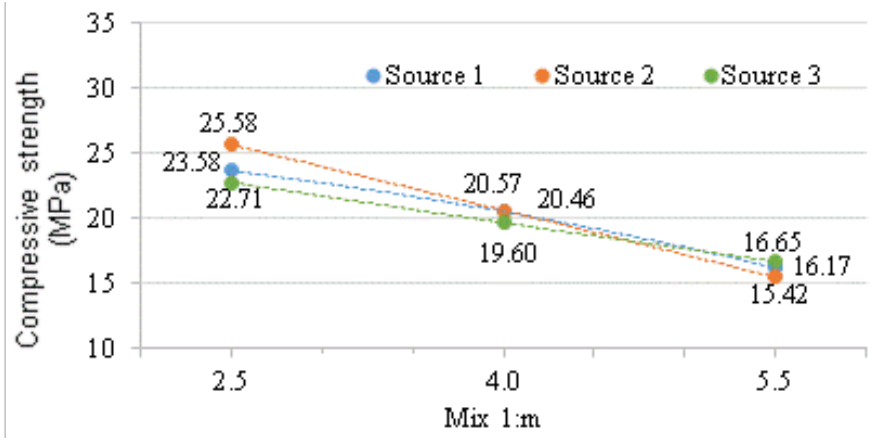

Figure 11. Effect of the mix-source interaction in axial compressive strength. 
In Figure 11, it can be seen that the recycled aggregates present different behaviors, as they come from the transformation of different materials, in which the variability of their characteristics, already presented, generate different behaviors and results for the compressive strength of concrete produced with these aggregates. Only in the richest mixes is it possible to prove the influence of the quality of the recycled CDW aggregate. Therefore, it is noticeable that the limiting factor for the improvement of the strength of the produced concrete was the aggregates, as the improvement of the matrix, with the enrichment of the mix and subsequent reduction of the water/cement ratio, generated slight increases or increases below expectations.

\section{CONCLUSIONS}

Considering the axial compressive strength, all results obtained with the types of concrete produced with recycled aggregates were lower than for those obtained with the reference aggregate, as predicted. The density selection reflected gains in compressive strength of the concrete produced with aggregates from source 1, for all mixes, ranging from $12 \%$ to $20 \%$. Nevertheless, for the other sources, no uniform behavior was observed, with strength losses even for the concrete produced with recycled aggregates that had undergone jigging.

Although the analysis of variance showed significant gains and considered the jigging process as having an impact on the values for compressive strength, complementary studies must be carried out to evaluate the feasibility of the implementation of the process, coupled with the gain it can provide.

The variability of the materials that make up the recycled coarse aggregates, which was noticed in the characterization tests, as well as the difficulty in promoting an effective separation of the materials, may have influenced the variability of the results of axial compression strength. One hypothesis was raised for the reason why the jigging process was not effective, which is the presence of enameled or polished ceramic lamellar material, which may have generated interferences in the density separation process.

Therefore, the use of jig for the selection of large aggregates of construction and demolition waste from commercial sources should be better studied and evaluated, to understand the phenomena and particularities of processing this type of material.

\section{ACKNOWLEDGEMENTS}

The Federal University of Rio Grande do Sul (UFRGS), the Graduate Program in Civil Engineering: Construction and Infrastructure (PPGCI), the Center for Innovation in Construction (NORIE), the Construction Environment Materials and Technology Laboratory (LAMTAC,) and the Mineral Processing Laboratory (LAPROM).

\section{CITATIONS}

[1] M. B. Leite, "Avaliação de propriedades mecânicas de concretos produzidos com agregados reciclados de resíduos de construção e demolição,” M.S. thesis, Prog. Pós-grad. Eng. Civ., Univ. Fed. Rio Grande do Sul, Porto Alegre, 2001.

[2] J. Santos, F. Branco, and J. Brito, Mechanical Properties of Concrete with Coarse Recycled Concrete Aggregates (paper 047). Oslo, Norway: Sustainable Building, 2002.

[3] E. Mulder, T. P. R. Jong, and L. Feenstra, "Closed Cycle Construction: an integrated process for the separation and reuse of C\&D waste," Waste Manag., vol. 27, no. 10, pp. 1408-1415, 2007.

[4] S. Luo, S. Ye, J. Xiao, J. Zheng, and Y. Zhu, "Carbonated recycled coarse aggregate and uniaxial compressive stress-strain relation of recycled aggregate concrete," Constr. Build. Mater., vol. 188, pp. 956-965, 2018.

[5] S. C. Angulo, "Caracterização de agregados de resíduos de construção e demolição reciclados e a influência de suas características no comportamento de concretos,” M.S. thesis, Prog. Pós-grad. Eng. Civ., Univ. São Paulo, São Paulo, 2005.

[6] A. Rao, K. N. Jha, and S. Misra, "Use of aggregates from recycled construction and demolition waste in concrete," Resour. Conserv. Recycling, vol. 50, no. 1, pp. 71-81, 2007.

[7] R. V. Silva, R. Dhir, and J. Brito, "The influence of the use of recycled aggregates on the compressive strength of concrete: a review," Eur. J. Environ. Civ. Eng., vol. 19, no. 7, pp. 825-849, 2015.

[8] C. Medina, W. Zhu, T. Howind, M. Frías, and M. I. Sánchez de Rojas, "Effect of the constituents (asphalt, clay materials, floating particles and fines) of construction and demolition waste on the properties of recycled concretes," Constr. Build. Mater., vol. 79, pp. 22-33, 2015.

[9] J. Pacheco, J. Brito, C. Chastre, and L. Evangelista, "Experimental investigation on the variability of the main echanical properties of concrete produced with coarse recycled concrete aggregates," Constr. Build. Mater., vol. 201, pp. 110-120, 2019.

[10] P. Kamrath, "Demolition techniques and production of construction and demolition waste (CDW) for recycling," in Handbook of recycled concrete and demolition waste, F. Pacheco-Torgal et al., Eds., Germany: Woodhead Publishing, ch. 8, pp. 186-209, 2013. 
[11] K. Pandurangan, A. Dayanithy, and S. Om Prakash, "Influence of treatment methods on the bond strength of recycled aggregate concrete," Constr. Build. Mater., vol. 120, pp. 212-221, 2016.

[12] R. S. Paranhos, B. G. Cazacliu, C. H. Sampaio, C. O. Petter, R. Oliveira No., and F. Huchet, "A sorting method to value recycled concrete," J. Clean. Prod., vol. 112, pp. 2249-2258, 2016.

[13] American Society for Testing and Materials, Standard Specification for Portland Cement, ASTM C 150, 2018.

[14] Associação Brasileira de Normas Técnicas, Cimento Portland Pozolânico - Especificação, NBR 5736, 1991.

[15] Associação Brasileira de Normas Técnicas, Cimento Portland Resistentes à Sulfatos - Especificação, NBR 5737, 1992.

[16] A. Lemos. "RES: caracterização de cimento". Apr. 24, 2018.

[17] Associação Brasileira de Normas Técnicas, Agregados - Determinação da Composição Granulométrica, NBR NM $248,2003$.

[18] Associação Brasileira de Normas Técnicas, Agregado - Determinação da Massa Unitária e dos Espaços Vazios, NBR NM 45, 2006.

[19] Associação Brasileira de Normas Técnicas, Agregado Miúdo - Determinação da Massa Específica e Massa Específica Aparente, NBR NM 52, 2009.

[20] Associação Brasileira de Normas Técnicas, Agregados - Redução da Amostra de Campo para Ensaios de Laboratório, NBR NM 27, 2001.

[21] Associação Brasileira de Normas Técnicas, Agregados para Concreto - Especificação, NBR 7211, 2009.

[22] Associação Brasileira de Normas Técnicas, Agregado Graúdo - Determinação do Índice de Forma pelo Método do Paquímetro Método de Ensaio, NBR 7809, 2006.

[23] Associação Brasileira de Normas Técnicas, Agregado Graúdo - Determinação da Massa Específica, Massa Específica Aparente e Absorção de Água, NBR NM 53, 2009.

[24] L. N. P. Cordeiro, “Análise dos parâmetros principais que regem a variabilidade dos concretos produzidos com agregados graúdos reciclados de concreto,” M.S. thesis, Prog. Pós-grad. Eng. Civ., Univ. Fed. Rio Grande do Sul, Porto Alegre, 2013.

[25] M. B. Leite, L. N. P. Cordeiro, A. B. Masuero, and D. C. C. Dal Molin, "Proposta de adaptação do procedimento proposto por Leite (2001) para determinação da absorção de agregados reciclados de resíduo de construção demolição," in An. Cong. Int. Patol. Reabil. Estrut., 2011.

[26] A. Coutinho, Fabrico e Propriedades do Betão. Lisboa: LNEC, 2000, v. I, II, III.

[27] C. H. Sampaio and L. M. M. Tavares, Beneficiamento Gravimétrico: uma Introdução aos Processos de Concentração Mineral e Reciclagem de Materiais por Densidade. Porto Alegre: Book, 2005.

[28] B. Cazacliu et al., "The potential of using air jigging to sort recycled aggregates," J. Clean. Prod., vol. 66, pp. 46-53, 2014.

[29] R. B. Silva, S. C. Angulo, R. G. Pileggi, and C. O. Silva, "Concretos secos produzidos com agregados reciclado de RCD separados por densidade," Ambient. Constr., vol. 15, no. 4, pp. 335-349, 2015.

[30] W. M. Ambrós, C. H. Sampaio, B. G. Cazacliu, G. L. Miltzarek, and L. R. Miranda, "Usage of air jigging for multi-component separation of construction and demolition waste," Waste Manag., vol. 60, pp. 75-83, 2017.

[31] C. H. Sampaio et al., "Stratification in air jigs of concrete/brick/gypsum particles," Constr. Build. Mater., vol. 109, pp. 63-72, 2016.

[32] M. G. C. Cunha "Viabilidade do uso de RCD proveniente da geração dos concretos convencional e Alta Resistência através da utilização do jigue como agente do beneficiamento,” M.S. thesis, Prog. Pós-grad. Eng. Min., Metal. Mater., Univ. Fed. Rio Grande do Sul, Porto Alegre, 2017.

[33] Cement and Concrete Association of New Zealand, Best Practice Guide for the Use of Recycled Aggregates in New Concrete. New Zealand: CCANZ, 2011, pp. 49.

[34] A. Coelho, and J. Brito, "Preparation of concrete aggregates from construction and demolition waste (CDW)," in Handbook of recycled concrete and demolition waste, civil and structural engineering, F. Pacheco-Torgal, V. W. Y. Tam, and J. Brito, Ed., Cambridge: Woodhead Publishing, ch. 9, pp. 210-245, 2013.

[35] P. R. L. Helene, and P. Terzian, Manual de Dosagem e Controle do Concreto. São Paulo: Book São Paulo, 1992.

[36] Associação Brasileira de Normas Técnicas, Concreto - Determinação da Consistência pelo Abatimento do Tronco de Cone, NBR NM 67, 1998.

[37] Associação Brasileira de Normas Técnicas, Concreto - Procedimento para Moldagem e Cura de Corpos de Prova, NBR 5738, 2015.

[38] Associação Brasileira de Normas Técnicas, Concreto - Ensaios de Compressão de Corpos-de-Prova Cilíndricos, NBR $5739,2007$.

[39] Associação Brasileira de Normas Técnicas, Concreto - Preparação das Bases dos Corpos-de-Prova e Testemunhos Cilindricos para Ensaio de Compressão, NBR NM 77, 1996.

Author contributions: DCDM and ABM: conceptualization, methodology, funding acquisition and supervision.

Editors: Jose Tadeu Balbo, José Luiz Antunes de Oliveira e Sousa, Guilherme Aris Parsekian. 